\title{
Globalization and the Intensification of Economic Problems as the Leading Factor of Nationalism Orientation toward Radical Islam in Central Asia
}

\author{
Mohammad Farhadi (Author) \\ $\mathrm{PhD}$ in Political Sciences \\ Seyed Salman Moradi \\ Graduate Student of Social Sciences
}

Doi:10.5901/mjss.2016.v7n3s2p128

\begin{abstract}
Many sociologists believe that people abandoned their traditional identity seek identity under the influence of fundamentalist ideologies in the era of globalization and most attracted to religious fundamentalism than ethnicity. Fundamentalist identities and movements make use of ethnic identities and ethnic influence spheres in a globalized world to provide better space for activities, such as the Taliban fundamentalist movement that relied on Pashtun, Afghan tribe, to survive against other Afghan tribes (For further information, refer to the books: Mario Diani, social movements and Castells, The Information Age). The main question in this article is: why nationalism in the era of globalization, unlike the historical background did not led to the formation of a national trend in the Central Asian countries and in contrary oriented toward radical Islam? In response to the question, it can be assumed that the phenomenon of globalization faced Central Asia countries which had serious social, economic, political, cultural and ideological problems with ethnic the nationalist identification emergence and spread. But, nationalism could not gain national orientation in these countries due to economic problems, and this time moved in the Islamic direction, making the project idea of "radical Islam" by the fundamentalist groups.
\end{abstract}

Keywords: Globalization, Nationalism, Islamism, Fundamentalism, Asia

\section{Introduction}

After the collapse of the Soviet Union, the return of millions of Central Asia Muslims in the Islamic world drew the attention of many analysts. In fact, the collapse of the Soviet Union was not only the cause of independence of the five Central Asian republics (due to the impossibility at the time of Soviet period), but the Muslim minority faith became the majority faith. The fact that religion can be considered as a strong element in political identity was considered as a characteristic of contemporary international relations in Central Asia foreign policy orientation as well as nationalism. In other words, the return of these countries in the field of Islamic culture was to the extent that exploited as a national characteristic features in these countries. The threat of Islamic fundamentalism was more evident in Tajikistan, Uzbekistan and Kyrgyzstan. In Tajikistan, the civil war of 1992 between the Communists and the nationalist forces increased the concerns about radical and fundamentalist Islam. These tendencies were grounded especially in the Fergana Valley and could also directly involve Uzbekistan and Kyrgyzstan in case of intensification (Hamid Reza Azizi, "strategic view of Russia to the south", CIS book (4, Tehran, Abrare Moaser Cultural Institute of International Studies, First Edition, April 2012).

\section{Nationalist Movements in the ERA of Globalization}

Globalization has strengthened two features of nationalist movements. First: the process of globalization weakens the standard power of nation-states that helps growing ethnic movements, governments were unique institutions to exercise power (the exercise of coercive power) prior to increasing rate of globalization. These states were able to control ethnic eccentric movements with dominance on economic information and communication resources of ethnic groups. But the process of globalization has stopped to nation states act any action through the supranational institutions forces, such as the UN and other international organizations and institutions. The organization's actions in the Iraqi war against Kuwait, or against Yugoslavia in country's ethnic conflict are supporting the idea. Second, satellite media, such as television and the Internet have provided access to information outside governments control for fans of nationalist movements, as well as 
facilitate the collection of human and financial assistance to their support. Thus, the governments cannot control nationalist movements. The second feature: that globalization adds to the number of people who need ethnic identification. People are more alienated of their familiar identities (a variety of traditional identities in the life of the village, nomadic and urban), and they are subject to civil identity (citizenship) and ideological Identities (identities based on ethnic, nationalist, liberal, and socialist identities) in modern society by gradual expanding education and communication (individualism). Globalization intensifies processes via wide spread of information and communications equipment. So, some individuals are attracted to ethnic identity for their identification by increasing globalization (Retrieved from Azerbaijan Student Movement Website: Inam, Savash, "The impact of globalization on nationalist movements", Tuesday, November 5, 2013). However, some sociologists do not confirm the above and believe that people abandoned their traditional identity in the era of globalization have affected by fundamentalist ideologies seeking their own identity and join more to religious fundamentalism and not ethnic ones. For example, Fundamentalist identities and movements make use of ethnic identities and ethnic influence spheres in a globalized world to provide better space for activities, such as the Taliban fundamentalist movement that relied on Pashtun, Afghan tribe, to survive against other Afghan tribes. Also, some sociologists believe that if by any reason, nationalism and ethnic movements are activated, the general trend of international actors acts in the context of state in order to control it in favor of citizenship nationalism. The ethnic upheaval in the 90's in former East bloc countries, in Africa and most recently in Afghanistan (after the September 11, 2001) confirm this and thus according to the sociologists globalization does not necessarily help nationalists movements (Mario Diani, "social movements and Castells", The Information Age). So, reviewing nationalism in the age of globalization, it is necessary to review the status of the phenomenon of globalization and its consequences and the reasons behind nationalism orientation in the direction of extreme Islamism in the Middle East in the light of globalization.

\subsection{The Consequences of Globalization in Central Asia}

Globalization is a process that ties all social, economic and security systems in the world deeply and closely to each other with great impact on each other, so that transformation and shift in one part of the world will have important implications on other sections. Global economic integration and thus the integrity of security issue is one of the most striking manifestations of globalization. The collapse of the Soviet Union and the independence of the countries in Central Asia and it coincided with the intensification of globalization; Asia has faced several ethnic crises as follows: Ideological crisis: Islamism and religious awakening that began in the 70s and intensified in the 80s, concerned The U.S, Turkey, Russia and some European countries, so that at the beginning of the third millennium, globalization project was introduced by The U.S to prevent Islam to become a global culture by digestion of the of the world cultures (Saeed Sherafat, "security in Central Asia", CIS book (CIS for security reasons), Tehran, Abrare Moaser Cultural Institute of International Studies, First Edition, April 2012. 90-92).

Historical identity crisis: The crisis started in the newly independent states of the former Soviet Union and the attempt to self-knowledge and return to the original culture of ethnic people living in Central Asia and the Caucasus, and one of the main causes of the collapse of the Soviet Union were of this crisis type (ibid, 91-92).

Spiritual and moral crisis: the crisis is beyond the region, country and even continent. Anti-religious trend in the last three centuries on the one hand and the dominant culture (libertarianism, humanism) incapacity to provide the correct interpretation of the universe on the other hand enclosed man in the grip of technology and modernity in such a way that spiritual went on amnesia and the idea of nihilism and egoism swiped him (ibid, 91-93).

Land and border crisis: victims of this type of crisis are in the colonies and in fighting countries and are predictable in the Central Asian republics with significant populations of Russia and neighboring countries with China, as we witnessed Kyrgyzstan protests against the government's policy of handing over part of their land to China last year (ibid, 91-93).

Political crisis: the occurrence of such a crisis is inevitable when there is a difference between political elites for power that leads to civil war as well. Central Asia region countries were no exception and have been involved with it from then (ibid, 91-93). The crisis has caused many problems for the government leaders of the countries of Central Asia so that the leaders of these countries who were incapable of providing internal and foreign security of their countries were inclined toward political-economic international cooperation to provide their security so that we are witnessing the globalization of the economy and security in Central Asia. Therefore, we can say that the process of globalization in Central Asia has two different outcomes; on the one hand globalization causes deviation of nationalist movements to fundamentalist religious movements such that much of sociologists speak of a radical Islam (Wahhabi Islam) in the region. On the other hand globalization has expanded the threat of radical Islamism in the region, so that in the opinion of Russian experts, including - Alexey Malashenko: Central Asia is more Islamic than before and "Soviet man" is gradually 
replaced by the "Islamic people" (though the phenomenon differes in different countries). Islamic trend in Central Asia does not occur with the same speed in all regions and is more evident in Tajikistan and Uzbekistan. The Islamic world encourages the process and supports Islamic education of youth, exports religious ideology to the region and spends money to establish a system of Islamic education and the construction of mosques. Central Asia has become the legitimate part of Islamic world and thus distanced from Russia. The spread of religious extremism is the essential aspect of Islamic process. So that this challenge can be considered both as external challenges (for international radical organizations have been working for many years in Central Asia), as well as internal challenges (as Islamist opposition are in all countries in the region). Therefore, international Islamist thereby arose that some Russian groups working with these organizations in Central Asia (Alexei Malashenko, "Who challenges Russia in Central Asia?", Nezavisimaya Gazeta, http://iras.ir/vdchxvni.23nkwdftt2.html, IRAS http://iras.ir, translator, author of the article, pp. 3-5).

\subsection{The general reasons for the spread of radical Islamism in Central Asia}

Corruption and bribery, rich and poor class-based society, Islamophobia, lack of attention to the promotion of moderate Islam, dealing with the original Islam movements in conflict with the terrorism and fundamentalism, having an inflexible rule for civil society, lack of attention to the democratic Islam based on the will of nation are among the very important issues in Central Asia and has caused people to have doubts on a future democratic and economic policy. Thus radical Islamists adopted of ideologies such as: belief in God, following the radical Islam and repression of enemies through jihad and emphasize on radical Islam, and insisted that only radical Islamic government can provide justice for the people and solve all the problems. The above factors has made radical Islamism as a serious threat to the region and that with the emergence of newly independent states of Central Asia, the region is home to some theorists of the ideology of "panIslamism" or "radical Islam". Some politicians believe that Central Asia may become the center of Islamic fundamentalism (Saeed Sherafat, "security in Central Asia", CIS book (CIS for security reasons), Tehran, Abrare Moaser Cultural Institute of International Studies, First Edition, April 2012, pp. 90-92).

\subsection{The economic problems as the causes of the trend of radical Islamism in Central Asia}

Isis and extremist religious groups campaigning is primarily based on economic and material interests, people of Central Asia join the ranks of the militia due to the inability to earn a living, and economic difficulties and failure, history of the people living in the area and convenient Geographical location of some areas in Central Asia for the development of the activities of religious extremist have created religious radicalism in the region. Due to these factors, many analysts know the growth of radical Islamism in the region a product of social - economic and cultural conditions of Central Asian countries rather than propaganda by foreign commissions. More than one third of population of Central Asia, especially Kyrgyzstan, Tajikistan and Uzbekistan live below the poverty line and lack the food safety with significant portion of the staple crop such as wheat, potatoes, onions and fruits imported from abroad especially from China and even Afghanistan. Unemployment is also other serious problems in these communities. According to the "International Labor Organization" in 2014, the unemployment rate in different countries of Central Asia is as follows, Tajikistan 8\%, Uzbekistan 10\%, Kyrgyzstan 8\% and Kazakhstan 5\% (http://www.farsnews.com).

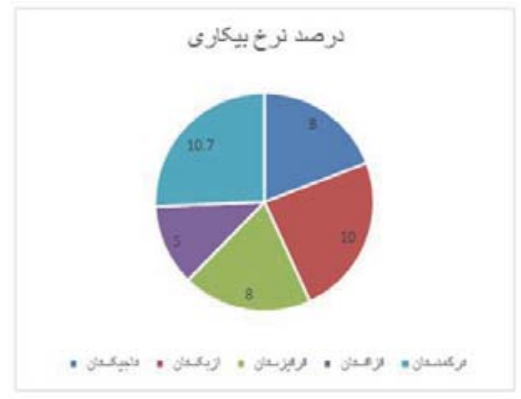

The latest report of "World Bank" reads that more than 47 percent of Tajikistan's population of 8 million people live below the poverty line, and struggle with the many problems of providing food supplies. Presidents and their families held more 
than 50 percent of wealth theses countries (http://www.farsnews.com). The issue of poverty and unemployment in those countries as well as the impact of the West sanctions against Russia affects $20 \%$ reduction in the number of immigrants and their income increased so that some special people have increased in their recent activity among immigrants, particularly among Tajiks working ones. There are five million Kyrgyzstan, Uzbekistan and Tajikistan labor migrants in Russia that indicates the bad economic situation of their countries. The minimum monthly income of workers in the republics of Central Asia was $\$ 19.1$ last year, which is an incredible figure. According to the study, the average monthly salary of civil servants in Tajikistan last year was $\$ 93$ and wages in the agricultural sector fluctuated between $\$ 35$ to and $\$ 80$ a month. The figure compared to the income of a family of four is minimal. Emomalii Rahmon, Tajik president, stressed the need to reform the new criteria in the revised cost of the household basket and said that Tajik citizen's monthly income of 25 dollars in last September should increase to more than $\$ 50$ in the current year.

The average monthly income per person in the Kyrgyz Republic is $\$ 210$, in Azerbaijan is $\$ 278$, in Armenia is $\$$ 375 and in Russia is $\$ 945$. The largest share of the GDP in the countries of the Caucasus and Central Asia in the last year was about 9 thousand dollars that owned by Cossacks. Tajikistan has the lower share in GDP among the countries of the Caucasus and Central Asia due to its low per capita income and a decrease in production caused by. The UN earlier said that more than 2.5 million people in Tajikistan are facing food shortages. Food and Agriculture Organization of the United Nations officials have said that up to 40 percent of the population suffers from hunger and malnutrition.

International institutions experts that have negotiated with Tajik farmers have expressed their concerns about the growing poverty among them; the price of bread in the country went up to 60 percent since 2007 (http://www.farsnews.com/newstext.php?nn=13940625000051). Farmers have said excess fuel prices have left a detrimental effect on wheat and other agricultural products. The ban on export of wheat from Russia and its role in the sharp rise in grain prices in the world markets and the growth of the sales price of Kazakhstan wheat to Tajikistan has played a significant role in exacerbating inflation and hunger. The 74 percent increase in the tariffs cost of goods purchased from Uzbekistan by Tajikistan also plays a large role in the growth of prices in this poor Central Asian country.

In the event that more than 65 percent of the seven million of Tajikistan population has no sufficient income and unemployment is the most important economic problems of the country, the increase in the price of commodities, especially food continues. According to unofficial data, the price of basic foodstuffs such as flour and meat excessively increased in Tajikistan even up to 50 per cent over the past year and concerned the poor and low-income population. Meat price on the Tajikistan market is now in seven dollars per kilogram, beef price is 6.2 dollars per kilogram, a bag of $50 \mathrm{~kg}$ flour is $\$ 22.5$, a kilogram of vegetable oil is $\$ 2.5$, and a kilogram of cheese is $\$ 7$ and a loaf of bread for 20 cents. In fact, with rising prices, the purchasing power of households on fixed incomes is less on a daily basis, so the most important food consumer products have been gradually removed from the food basket. The price per liter of gasoline has increased from a dollar to a dollar and 70 cents over the past year. Lease of residential units of 60 meters in Dushanbe in lower class regions is about $\$ 200$ and is more than 700 dollars in the city center. Rates of public utilities such as water, electricity telephone and tax have risen up to more than 50 per cent since last year that tightened the living conditions for the families of Tajik, so that current wages of do not supply daily necessities (http://www.poolnews.ir/fa/news/61697). Economic problems led to Islamist groups enjoying wide publicity to attract people seeking to join the Central Asian groups are infidels. "Nicolas Bardyvzha" Secretary-General of the Commonwealth said Collective Security Treaty Organization had been identified and suspended more than 57 thousand websites that hire people, especially the youth of Central Asia to the ranks of the terrorist group of the Islamic State. He added currently, 50 thousand of these websites have been suspended and investigation in the others is continuing. General of the Commonwealth continued that Propaganda websites are highly active in Central Asia with the aim of creating extremism in area, which unfortunately these activities have been increasing in the last few weeks. For example the words by "Victor Mikhailov" an Uzbekistan security expert in this regard is remarkable. he According to documents, said that this year (2014) more than 300 citizens of Uzbekistan joined the Islamic State and the majority of them after the disappointment of obtaining financial conditions trapped in ISIS missionary group in the territory of Russia (http://www.farsnews.com).

\section{Globalization, Intensification of Economic Problems and Nationalism Orientation toward Radical Islam}

The consequences of ethnic globalization are divided into three groups: weakening the state- nations, strengthening ethnic identity growth and creating virtual ethnic communities. The aim of the international community in this century is to replace the at least government to the maximum and totalitarian government and thus despite the weakening of the statenations refers to the growth and strengthening of ethnic identity and is associated with it. Globalization will give rise directly or indirectly to ethnic identity. Globalization shifts attitude and orientation of different classes from political and social issues to cultural ones, and thus brings insiders and outsider's elements that are exploiting and exploited class into 
cultural areas, especially ethnic groups and makes ethnic identity the basis of much of the global system challenges in future. Globalization encourages multiculturality - multi-ethnicity at the micro level - but leads to cultural homogeneity at global macro-level and pursues the same orientation and the same objectives in the global hybrid system. Extreme nationalism decreases in line with moving away from the government centrality and weakened overall trends and norms and dominant states, and transnational and subnational identities increases with premiere role of individuals, groups and civil society organizations including the ethnic groups. The move toward globalization and the establishment of global culture and identity was promised in many communities as a result of pursuit of utopia that discrepancies between perceptions and realities arise if these expectations are not met and in turn causes insecurity and confusion and there will be no solution but to return to the minority own identity in order to create security and identity. The national independence has failed to capture the imagination of most of the Central Asian countries, and this is a situation that living conditions are getting worse (Fakham Aqdami, "Ethnicity and globalization", Teachers and the academic elite thinking website, pp. 3-5.). This has made people to reject political legitimacy of projects by young nations. This, combined with the lack of economic development in the region adds to the crisis of legitimacy so that only Kazakhstan during the Soviet period had a significant rate of economic development in the region and the rest of the countries were the least developed of the former republics. Therefore, these republics after independence were faced with the problem of socio-economic development and the lack of strong management potential and structure.The republics lacked trained staff and financial empowerment and also the Central Asian states natural resources development and economic structures and wealth differ, and to exploit them, require huge capital and modern technology and thus they compete with each other, as well. This made solidarity social network act as the main power. Contrary to the idealist groups that, a decade ago, called for a regional alliance under the Turkic unity, today the networks seek regional integration under the banner of Islam. It is a necessity to re-evaluate the role of Islam in the past and present in central Asian societies in the repression and collapse of communist ideology. Now, the society is even more Islamic while suppressing Islamic political groups and the various sects continues and this is true in even Kazakhstan and Kyrgyzstan and thus political Islam is becoming more radical (Vigen Chatriyan, "Central Asia, nationalism and Islamism in the conflict", journalists and special envoy of Le Monde Diplomatique, 2013, pp. 4-7) . Therefore it can be said that globalization impacts on nationalism in Central Asia in two different ways: on the one hand, weakened national states and accelerated ethno-nationalist and on the other hand, Central Asia countries are facing serious economic problems caused by a rapid emergence and spread of ethnic and nationalist groups. However, nationalism could not gain national orientation in these countries due to economic problems, and this time moved in the Islamic direction, making the project idea of "radical Islam" by the fundamentalist groups.

\section{Conclusion}

After the collapse of the communist ideology of internationalism and national politics associated with it that has put in order ethnic-based interests in Central Asia during the Soviet state, the ethnic diversity of Muslim societies were deprived of such an important regulation. In such a situation, Islamic ideological, as an ideology that brings human beings not by their ethnicity, but powerfully unifies them was welcomed by Central Asian countries and acted like interface to regulate relations between peoples. Therefore, Islamic movements gradually lost its national ting and gained Islamic orientation. Deteriorating economic situation in Central Asia, the regional government's inability to solve economic problems as well as strengthen the crackdown on Islamists has added to the problem. The current situation in the region has two features: first the deterioration of the socio - economic condition, and second the deterioration of the political environment. Now we can answer the question that why nationalism in the era of globalization, unlike the historical background did not led to the formation of a national trend in the Central Asian countries and in contrary oriented toward radical Islam? In response to the question, it can be assumed that the phenomenon of globalization faced Central Asia countries which had serious social, economic, political, cultural and ideological problems with ethnic the nationalist identification emergence and spread. But, nationalism could not gain national orientation in these countries due to economic problems, and this time moved in the Islamic direction, making the project idea of "radical Islam" by the fundamentalist groups.

\section{References}

Mario Diani, "Social movements and Castells", The Information Age

Hamid Reza Azizi, "Strategic view of Russia to the south", CIS book (4, Tehran, Abrare Moaser Cultural Institute of International Studies, First Edition, April 2012

Azerbaijan Student Movement Website: Inam, Savash, "The impact of globalization on nationalist movements", Tuesday, November 5 , 2013 
Fakham Aqdami, "Ethnicity and globalization", Teachers and the academic elite thinking website

Vigen Chatriyan, "Central Asia, nationalism and Islamism in the conflict", journalists and special envoy of Le Monde Diplomatique, 2013

Alexei Malashenko, "Who challenges Russia in Central Asia?", Nezavisimaya Gazeta, http://iras.ir/vdchxvni.23nkwdftt2.html, IRAS http://iras.ir, translator, author of the article

Saeed Sherafat, "security in Central Asia", CIS book (CIS for security reasons), Tehran, Abrare Moaser Cultural Institute of International Studies, First Edition, April 2012

http://www.farsnews.com

http://www.farsnews.com/newstext.php?nn=13940625000051

http://www.poolnews.ir/fa/news/61697 